\title{
Making ends meet in financial scarcity in old age
}

\author{
By RIKKE NøHR BRÜNNER*
}

\begin{abstract}
The purpose of this paper is to explore qualitatively how older people (aged 69-85 years) living in relative poverty experience their daily life and how they make ends meet $(N=16)$. The empirical analysis shows that despite deprivations, the interviewees are mostly satisfied, and in order to analytically understand this satisfaction I draw on three individual and structural aspects: (1) The Danish welfare state ensures the interviewees' basic ontological safety. (2) As the interviewees lived in financial scarcity during other phases of their lives, they are familiar with being thrifty, and they have a practical sense of making ends meet. (3) Although none of the interviewees had saved up for their retirement, some had saved up social capital, which enables them to modify or take a break from financial scarcity. Thus, although the interviewees' financial capabilities are similar, their actual daily lives are very different from each other.
\end{abstract}

Keywords: aging, daily life, financial scarcity, poverty, state pension.

${ }^{*}$ Rikke Nøhr Brünner, VIVE - The Danish Center for Social Science Research, Copenhagen, Denmark 
International Journal of Ageing and Later Life

\section{Introduction}

Approximately one in six Danish state pensioners live entirely or primarily on a social state pension, ${ }^{1}$ which provides a disposable income close to $60 \%$ of the median income in Denmark, making them objectively at risk of experiencing relative poverty, according to the official European Union (EU) definition. ${ }^{2}$ The 1990's pension reforms in most European countries decreased the ability of the systems to prevent and reduce poverty in old age (Grech 2012; Schwartz 2006). Thus, relative poverty in old age remains an issue. In quantitative studies, low income in old age has been linked to a series of poor outcomes, such as lower life expectancy (Baadsgaard \& Brønnum-Hansen 2012), lower general well-being (Golden et al. 2009), social exclusion (Mood \& Jonsson 2016), and psychological distress and worry (Keith 1993; Litwin \& Meir 2013; Litwin \& Sapir 2009). Such studies on income poverty are important, as they provide information about the individual's consumption power and how many individuals are above or below the poverty threshold (Andersen et al. 2013). However, studies on income poverty do not inform us about what standard of living, or daily life, is possible within these financial frames, or how living within these financial frames is experienced. Several studies showed that there is not necessarily a direct link between objective living conditions and the economy on one hand and an individual's subjective life satisfaction on the other hand (Allardt 1975; Leeson 1999; Longva 1993). To understand how old age poverty is experienced and managed, we need knowledge of older people's daily lives. Therefore, focusing on subjective experiences, I investigate how state pensioners living in financial scarcity experience and manage their daily lives.

\section{Background}

Stjernø (1985) characterized modern poverty as a tyranny of financial scarcity because poor people struggle to make ends meet and participate in activities in which other people participate. However, if poor people

${ }^{1}$ Defined as disposable income, in addition to the social state pension, at a maximum of 100 Euro per person/month.

2 Sixty percent of the median income in Denmark is DKK 128.400 (2014). 
refrain from spending money in other domains, they are able to create opportunities to participate to some extent in a life that is considered normal in the social context. Thus, to obtain a small bite of the wealth evident among those in the surrounding society, modern poverty requires careful prioritizing, saving, and renunciation. However, modern poverty leads to feelings of humiliation and shame, creates a dependence on limited welfare benefits, and often forces individuals to accept presents or handouts from family members (Stjernø 1985).

Because old age is socially constructed as a phase of retirement (i.e. outside the labor market), older people have only a few actual possibilities of changing their financial situation (Phillipson 2013). Thus, poverty in old age differs from poverty in other phases of life because it is often persistent (Gabriel et al. 2015). In contrast, younger people for whom the primary cause of poverty is unemployment have the possibility of taking on a job and actively moving out of poverty. However, individuals who are unable to work due to poor health, a lack of qualifications, and/ or a lack of connection to the labor market do not have the same actual possibilities of improving their financial situation (Ejrnæs et al. 2015). As is the case with the younger people who for different reasons are unable to work, older people in poverty have very limited possibilities for improving their financial situation. Taking on a (part time) job in order to earn more money is not necessarily a solution, primarily because of poor health. Second, because income from work will be set off in the pension payments, that is, any income exceeding DKK 20,500 (USD 3272) for singles, and DKK 40,600 (USD 6479) for married couples/cohabitants causes offsetting in the state pension. ${ }^{3}$ Thus, older people's only actual possibility is to accept and adjust to a life in financial scarcity (Brünner \& Andersen 2018).

Nevertheless, only a few studies have examined how older people living in financial scarcity actually experience and manage their daily lives. These studies have shown that older people living in financial scarcity apply various savings strategies to make ends meet (Dominy \& Kempson 2006; Finch \& Elam 1995), and that old people tend to experience a life in financial scarcity differently from younger people. For example, older

${ }^{3}$ Exchange rate $=626.60$. 
people would rather do without than incur debt, and they experience less subjective deprivation compared to younger people in the same financial conditions (McKay 2004; Price 2010; Scharf et al. 2006). Older people living in financial scarcity often underestimate the severity of their financial scarcity because they lower their expectations and, thus, accept that they cannot afford certain things (McKay 2004). Therefore, the oldest of the old $(80+)$ worry less than the youngest of the old, and this is an important empirical point to keep in mind when studying financial scarcity in old age (Litwin \& Sapir 2009). Dominy and Kempson's (2006) study suggested that to understand older people's experience of deprivations, it is essential to consider age and poor health, family support, and lifetime income and standard of living (Dominy \& Kempson 2006). A qualitative study on female state pensioners living in financial scarcity in Denmark also showed that different aspects of the individual life course are important when trying to understand how older people in financial scarcity cope with the situation and why they do this in different ways. The women in the study perceived their current life phase in old age as representing freedom due to an absence of duties, such as taking care of the household and childcare, which they dealt with during previous phases of life. Thus, despite financial scarcity, many experienced a good old age (Due 1994).

Studies in the field of old age and financial scarcity have documented some of the challenges and risks that are prevalent among this population, and they have indicated the importance of considering the individual's life course, social relations, and the societal context when examining poverty in old age. However, we know only little about how everyday life near the EU's official poverty threshold is actually experienced and managed by the old people themselves, thus we need more information on subjective everyday life and how this is affected by individual and structural factors. Therefore, to close the knowledge gap between the objective financial living conditions and the subjective experience, the following research question guided this study: How do Danish state pensioners living in financial scarcity experience and manage their everyday life?

Based on empirical findings, this study combines individual and structural explanations. Thus, in order to understand the everyday life it takes into account the significance of both the welfare state context and experiences in the individual life course. The study is theoretically founded in Bourdieu's concept of practical sense, which has some implications 
regarding the levels of explanation included. Thus, focus is not only on the interviewees' current life but also on experiences (of financial scarcity) in previous life phases, and how these factors shaped the way the current life is experienced and managed.

\section{Everyday Life in Light of Habitus and Practical Sense}

The analysis combines an everyday life perspective with the Bourdieu (1990) perspective of habitus and practical sense to understand the everyday lives of older people living in financial scarcity in the societal context. To understand how the interviewees experience old age in financial scarcity, an everyday life perspective is applied. However, a crucial assumption in this paper is that older people's ways of understanding their everyday lives are not just individual or arbitrary and might be a pre-reflexive product of their habitus and practical sense. Therefore, this paper also aims to understand why the interviewees perceive their everyday lives in the way they do.

An everyday life perspective is applied as an overall theoretical framework: This perspective comprises a field of meanings centered on how people experience, interpret, and discern what it is like to grow older and be old. The everyday life perspective centers on subjective meanings that might appear to the individual as objective facts but inform us about older people's feelings, thoughts, and methods of understanding their world, that is, a focus on the simple and regular rhythms that constitute everyday life. Through the everyday life perspective, the focus is to understand how the poorest state pensioners interpret and manage the financial scarcity of their daily lives. If we fail to listen to the voices of older people, we risk that the societal negative stereotypes regarding older people dominate. For example, an 80 -year-old person might not necessarily first identify himself or herself as an old person, although his or her social surroundings and society would not hesitate to define him or her as old. The everyday lives of older people are actually founded on universal human aspects, such as friendships, caring for loved ones, getting by in daily life, moving considerations, and so on (Gubrium \& Holstein 2000). Thus, the aim of applying an everyday life perspective to the empirical data in this study is to gain knowledge of how they experience and handle the part of their everyday life consisting of their financial situation. 
International Journal of Ageing and Later Life

In contrast, Bourdieu offers a framework to explain why the natural and taken-for-granted world is created in terms of habitus and practical sense. Bourdieu $(1990,1993,2000)$ emphasizes the importance of acknowledging the wider social context and structural factors, and his concept of habitus bridges the individual and collective experiences because the habitus is simultaneously individual, collective, and societal. In addition, Bourdieu (1990) defines habitus as the pre-reflexive dispositions inscribed in the individual, while ensuring that the individual's inner aspirations and actual possibilities correlate. Therefore, the most improbable things are excluded as unthinkable by a submission to make a virtue of necessity. Past experiences are actively present in the habitus, and they are manifested through schemes of perception, thought, and action, thus ensuring a "correctness" (Bourdieu 1990:54) of practices over time with much more accuracy than can explicit norms - that is, the inner system of dispositions functions like an internal law making sure that the external norms are constantly exerted and reproduced. This system of dispositions is a kind of present past, which perpetuates into the future. Thus, habitus is the generator transforming the characteristics of one's social position into one's overall lifestyle (Bourdieu 1990).

An individual's habitual choices in everyday life are guided by practical sense. Bourdieu (1990) describes practical sense as a feel for the game, which is founded in the social field in which the individual is socialized; the individual, thus, has impressive internalized knowledge of how to act in the specific field. Practical sense offers a way of relating to the world in a natural way, without having to reflect on how to act. Because native membership in a field implies a feel for the game, everything that takes place in the game seems sensible - full of sense and objectivity (Bourdieu 1990).

\section{Social Capital}

Social capital involves social obligations or connections accumulated through membership and provides members with the backing of collectively owned capital, a credential that entitles them to receive different kinds of credit. Through a social network, the individual has access to and can draw on different kinds of actual or potential resources available. Thus, the volume of an individual's social capital depends on the size of 
the social network of connections that he or she can mobilize and on the volume of capital (economic, cultural, or symbolic) possessed by those to whom the individual is socially connected. Therefore, to some extent, social capital depends on economic and cultural capital because it exerts a multiplier effect on the capital an individual possesses. Social network relationships result from investment strategies (individual or collective) aimed (consciously or unconsciously) at creating or reproducing usable social relationships, for example, through family relations, and these relationships are reproduced endlessly. The exchange of things between members is a symbol of recognition that reproduces the group's membership (Bourdieu 1986).

\section{Methods and Data}

This paper draws on life story interviews with 16 Danish state pensioners living in financial scarcity on the margins of relative poverty. The interviewees' financial scarcity is illustrated by the large inequalities in their disposable income compared with an average Danish state pensioner. The average disposable equated income for a Danish state pensioner in 2016 was DKK 17,512 (USD 2795) a month (private calculations from Statistics Denmark 2018), while the state pensioners included in this study receive approximately between DKK 9500 and 10,600 (USD 1532-1692) a month from state pension (basic amount and supplement) and ATP. ${ }^{4}$

This study is empirically founded in qualitative interviews with a vulnerable social group, thus ethical considerations are crucial. The study was registered and approved by the Danish Data Protection Agency, as legally required in Denmark. Further, I have followed ethical guidelines as provided by Brinkmann (2015). Prior to the interviews, I have obtained an informed consent from the participants. All interviews are anonymized, for example, original names of persons, places, and recognizable details in their life stories are blurred.

The participants were 3 men and 13 women living in rural and urban areas in Denmark, aged between 69 and 85 years. Three participants

\footnotetext{
${ }^{4}$ ATP is a Danish abbreviation, which in English means "The labour market's additional pension." It is a lifelong pension paid out every month.
} 
International Journal of Ageing and Later Life

have been disability pensioners for all or most of their adult lives, seven interviewees had held skilled positions (i.e. office assistant, dental technician, glazier, art school teacher, yoga teacher, bus driver, and hair dresser), and the rest primarily held unskilled employment (i.e. cashier at a grocery shop, factory worker, cleaning lady, and working at a pub). All live in private homes, except for one who lives in a nursing home. Only four cohabit with a partner. They all live entirely or primarily on social state pensions.

All of the interviews were conducted and digitally recorded in the interviewees' homes. The interviews were semi-structured and centered on issues such as the subjective experience of the financial situation, their actual budget, deprivations, health, life stories, daily lives, and social relations. During the interviews, I purposefully avoided using the term poverty to allow the interviewees to define their situations. All of the interviews were transcribed verbatim and coded in NVivo.

The recruitment strategy was based on two criteria: (1) The interviewees' income consists of primarily or entirely a state pension, appendixes and ATP, and (2) the interviewees are state pensioners. The participants were recruited for this study through different channels. Most of the participants - 14 out of 16 - were recruited through my personal or professional network. Five people were recruited through my personal network and, thus, are friends and family members of my friends and family. Nine were recruited through my professional network with an organization either because they receive formal visits from a professional care worker from community care (six) or because they are volunteer visit friends for other older adults (three), and two participants were recruited through a senior club, where I attended a social afternoon meeting. I did not know any of the interviewees before they were recruited.

Financial capacity is often considered a private matter. However, to recruit interviewees for this study I had to verbalize this private subject. When recruiting, I carefully avoided using normative terms such as poor, financial scarcity, and the like; instead, I verbalized the study using more neutral and open terms. Thus, I explained that I was conducting a study of the everyday on a social state pension, and that the object was to get insight into and knowledge of what everyday life for state pensioners living primarily or entirely on a state pension looks like. 
Financial scarcity in old age

\section{The Interview Context}

It is important to take into account the specific context of the interview as this affects the outcome. Thus, the meaning created in an interview situation also reflects the social positioning of the interviewee and the interviewer (Schultz 2005). Therefore, age, gender, social class, race, and other social categorizations affect the interview situation and, thus, the knowledge production. If the interviewer and the interviewee belong to different social categories, this difference might enhance the impact of the social categories because of the social distance in the interview situation (Miller \& Glassner 2011). The primary social positionings at stake in the interview situation are the distinction between young(er) and old(er) and between rich(er) and poor(er). It is impossible to account for the impact these categorizations may have had in the specific interview settings. However, the categorizations might have caused the interviewees (consciously or unconsciously) to attempt to downplay the severity of their financial scarcity, which might have been enhanced by the stigma associated with poverty (Lister 2004).

Nevertheless, I find that the knowledge produced in an interview should not be seen as only a product of the interaction and positionings in the specific interview context. Valid knowledge of the social world is also produced when the researcher lets the research object appear, that is, being loyal to the actual character, letting him or her define his or her own lifeworld, and letting him or her ask questions using his or her own words, not the researcher's words (Kvale \& Brinkmann 2015). Thus, when I recruited and interviewed the participants and analyzed the empirical data, I made sure not to define financial situation and daily life, to invite the interviewees to define the terms using their own words. Further, I focused on letting the empirical material speak for itself, thus, for example, not "drowning" the voices of everyday life in overshadowing theory, to ensure loyalty toward the empirical material.

\section{The Analytical Approach}

The object of the everyday life perspective is to let the interviewees define the financial aspect and what this means for their everyday lives. The themes in the analysis are based on the empirical findings. However, assuming that social structures play a crucial role in determining which 
International Journal of Ageing and Later Life

lifestyle an individual takes for granted and is adapted to, Bourdieu's (1990) perspective of habitus and the logic of practice are applied. The aim of the analysis is to understand the interviewees' individual everyday lives and to establish how their (seemingly) individual life stories are connected through a shared practical sense with a social origin. Thus, the use of life story interviews serves two purposes: (1) obtaining a nuanced and detailed insight into how state pensioners in financial scarcity experience their everyday lives and (2) determining how social relations play a part in their everyday lives. Bourdieu's (1986) concept of social capital is applied to analyze how the interviewees experience social capital and establish the kinds of help they receive in their everyday lives.

A life story represents an individual's self-presentation of life that is wrapped in external cultural factors and internalized social rules, codes, and values that the individual has accumulated through life (Hoff 2006). Therefore, it is possible to improve our understanding of how older people experience their everyday lives if we also know something about their past. Despite being unique, each life story also reflects dispositions of habitus shared by people with similar social backgrounds as a collective habitus, and, thus, inform us about a shared social world. This shared world means that an individual's experiences of his or her everyday life are not purely of individual origin or a matter of coincidence but also reflect the pre-reflexive habitus and the wider social context in which the individual is situated.

\section{Results}

\section{Satisfaction with Everyday Life}

I did not explicitly ask the interviewees if they were satisfied with their financial situation, or with their life in general. Nevertheless, a general feeling of contentment runs through the interviews. To exemplify I present an extract from the interview with 75-year-old Johanne:

Now that I'm in my - well, it must be called "old age", when you're 75, right, I don't know - I reflect. I think about, and I make sure that I take care of the days, and that I enjoy them. That how it must be. When you go to the library and see the great supply, it's unbelievable. I like reading. I ride my bike up there, have a cup of coffee, it's 20 DKK [USD 3.00] with cake. And I read those magazines and newspapers I feel like reading, and afterwards, I go upstairs and find a DVD and some music and whatever I feel like reading. Isn't that a luxury? 
She captures the general feeling of satisfaction with everyday life in financial scarcity, which I find in the interviews. This general feeling of satisfaction is motivating the empirical analysis as it raises the question of Why? - Why are they satisfied with a life in financial scarcity? In the next section, I present the analysis of how the interviewees manage their scarce everyday lives, which is crucial in order to understand this overall satisfaction. Thus, in the analysis, I link this feeling of satisfaction to their ways of managing their financial scarcity.

\section{The Importance of Being Anchored in Social Networks}

The participants' experiences of everyday life in financial scarcity heavily depend on what kind of help is available to them through their social networks. However, the interviewees have remarkably different resources available through their social capital. For example, 70-year-old Margret, who has an impressive social network, noted, "It [life in financial scarcity] depends very much on what kind of helpers you have in your life."

In contrast, 79-year-old Wilfred exemplifies poor social capital: Wilfred suffers from heart trouble, kidney failure, inflammation of the nerves, and posttraumatic stress disorder, and he lives alone in a run-down one-room apartment. He has no children or other family members, and no friends with whom he socializes at home; thus, his social network is very limited. He goes to dialysis 3 days a week, and he spends his afternoons on the other days at the local pensioner's club playing cards. A professional care worker from community care also visits him for 1 hour every second week. These visits are precious to him because they are his only source of practical help and emotional support. At the end of the interview, when asked if he wants to add anything to what has been discussed, he explains (once again) that he really misses having someone around to help him with practical things:

Well, as I've told you several times, I miss having a person to help me with small things. You know what, I'll give you an example. When I first moved in here, the moving boxes were all over the place for months. But then I did manage to get help to move them; otherwise, I wasn't able to sleep. But they have been here until now. It [the apartment] was without illumination, it was all dark in here. I tried to install lights with a small ladder. But the ladder fell, it was very unfortunate... One reads so many splendid things about handymen from the municipality coming to help with that sort of thing... The janitor says that he doesn't have the time for it... (from interview with Wilfred) 
International Journal of Ageing and Later Life

Wilfred is alone in the world, and the social capital available to him for emotional, practical, or financial help is limited or nonexistent.

By comparison, the majority of the interviewees have more resources in their social network because of their children, which they draw upon when necessary. For example, some reported receiving help with practical matters, such as writing applications or other kinds of communication with the municipality, moving, cleaning the windows, or being picked up and brought back home after social family gatherings. Others receive help related to financial/material matters, such as inheriting their children's electronic devices; receiving a new $\mathrm{TV}$, coffee machine, or glasses when the old ones break; or receiving spending money when needed. Seventyfour-year-old Inga explained that her son is always there for her, and he recently helped her by paying for her new glasses because he wanted to repay her for all the times she helped him earlier in his life:

Interviewer: What if your television breaks?

Inga: $\quad$ Then I'll die! ... Then my son is going to bring me a television right away.

Interviewer: He sometimes helps you financially?

Inga: Yes. Also, there was one year, which was last year, that I needed new glasses. But I had to wait for the elderly check. ${ }^{5}$ Then the day after he called me and said, "Let's go for a ride!" We went to the optician, and he said, "Go inside and buy yourself some new glasses. Now!" And then he went inside and paid for them. When I received the elderly check, I said to him, "Here you are!" "No! How many times have I received from you during my entire life?! Now you are getting something from me," he said.

Seventy-year-old Margret is a widower and lives alone in an apartment in a Danish city. She lived most of her adult life in the countryside with her husband and three children, and although she was educated as a librarian, she never worked as one. Instead, she taught yoga classes and created art, which she sold from time to time. She never had a high income, but

5 The elderly check is a lump sum paid out once a year to economically disadvantaged elderly. 
she is used to drawing upon a barter economy and her large social network that consists of people rich in different forms of capital. For example, sometimes they would buy an entire deer from the local hunter for only DKK 400 (USD 60), and they could often get pheasants almost for free. Thus, she and her husband were able to throw large parties in the summer and invite their yoga students and many other friends. Margret continues this way of life in her old age, although she now receives more than she contributes. She sums up this theme in her life as follows:

When Michael [one of her younger friends who imports wine and owns several prominent restaurants] said, "Well, do you want to join some French winegrowers on a tour this Saturday?" I texted him back, “But I don't speak French?" Then I bumped into him at the station, and he said, "But, you know, other people are paying for this!"

$[\ldots]$

And then we sailed, from one gourmet restaurant to the next, Saturday mid-morning, and with a wineglass on the boat, all the time filled with wine, and then a winegrower presented this wine, and then we drank, and then we made land and entered some fancy restaurant, and they made a course, and we had some other wine there, which one of them presented, and then we went back to the boat again [...]: This is pretty much my life because I know an unbelievable number of people, and because Conrad [her deceased husband] did so many things for many of those people and they think that we have been friendly and welcoming to them; thus, they do something for me now. (from interview with Margret)

Margret socializes regularly with her children and many friends. Throughout their lives, Margret and her husband managed to create a large social network consisting of many different people, and the capital they accumulated in their social network is now paying off in various ways.

A consistent theme throughout the interviews is that many of the participants receive help from their social network today because in earlier phases of their lives, they were always there when their friends and family needed help. Therefore, although none of the participants had saved up for their old age financially, those who saved up social capital are now being repaid through access to the capital available in their social networks. Social networks have a value that goes beyond the immediate value of being together. Thus, by participating in social relations, individuals can access resources possessed by other individuals in their social network. Social capital (alongside other forms of capital) is also defined as accumulated labor that is immanent in relationships between individuals and can be transmitted through time (Bourdieu 1986). Therefore, social 
International Journal of Ageing and Later Life

capital functions as a kind of investment made during earlier phases of life, which pays off later when needed. The social anchorage has a crucial impact on everyday lives of the interviewees who have social capital available, because it enables them to modify or take a break from the otherwise overpowering financial scarcity by allowing them to access capital that would otherwise be out of reach due to their financial conditions. However, as described, social capital is not available to all of the interviewees and, thus, represents a crucial difference regarding their experience with and possibilities of making ends meet in financial scarcity in old age.

The next section analyzes how the interviewees - regardless of their social capital - manage to get by in their everyday lives of financial scarcity. Although the analysis of social capital reveals large differences between the interviewees, the focal point of the subsequent analysis is the significant similarities in how they experience and manage the scarcity of their everyday lives.

\section{Ensuring Ontological Safety}

The interviewees explain that they have little knowledge or interest in managing their budgets (except for spending their disposable amount after paying fixed expenses). Thus, the responsibility for managing their budgets is outsourced to the bank, which pays all fixed expenses automatically. The interviewees are spared the worry of financial uncertainty, leaving them with a small fixed amount for groceries and pocket money, which they can spend as they please every month.

As the majority of the interviewees live in elderly senior apartments rented through the municipality, the rent and housing subsidy are automatically deducted from their state pension; thus, paying rent is not a concern. For those living in privately owned apartments or houses the housing costs are not automatically deducted from the state pension. Nevertheless, they are not concerned about the rent either, because not paying rent is unthinkable. When I ask Violet if she has ever failed to pay her rent on time, she replies:

Violet: $\quad$ No, no, no, never! That might be the last thing happening on Earth. I'll tell you that! No, that doesn't happen for me. In fact, it never happened for anyone in my family that I know of [...]. But I do support the homeless people as well.... 
Interviewer: Okay?

Violet: I must admit that. And I buy their paper every time I pass by, and every month. I don't buy two issues of the same paper, but I pay them more than the 20 DKK [USD 3.2] it costs; I might give them 30 DKK [USD 4.8]

Interviewer: How generous of you to do that!

Violet: Well, I get to eat every day; they don't, right?

This extract captures the interviewees' general viewpoint that always paying rent is natural and taken for granted. It is unthinkable to postpone paying it because they are aware that it is crucial to avoid homelessness, and by prioritizing their rent payments, their basic ontological safety of having a home is secured. Violet also illustrates the relativity of financial scarcity; that is, she helps homeless people because she realizes that she is in a better situation than they are. Therefore, despite not having much, approximately half of the participants share their awareness that other people are in worse situations, which illustrates the interviewees' appreciation of their own basic security.

Expenses for medicine, dental care, and other health-related issues also are not a concern or unrealistic expense for the interviewees because the Danish welfare state provides an important safety net in this regard: Financially disadvantaged state pensioners can apply for a health allowance (all the interviewees in this study are included in this group). The health allowance is a continual benefit that is automatically renewed every year if the person is still entitled financially, and the health allowance ensures that $85 \%$ of the expenses for medicine and dental care are automatically covered by the municipality. Further, the extended health allowance covers other health-related lump sum benefits, such as dental prostheses, glasses, and regular foot care. To receive benefits from the extended health allowance, citizens are required to apply for coverage before buying or ordering a product (borger.dk 2018). The interviewees consider this welfare state benefit essential because otherwise they might not be able to afford necessary medicine.

This section shows that the basic ontological safety is ensured at two levels. First, the welfare state provides a financial safety net by providing a housing subsidy, deducting the rent from the state pension, and minimizing health expenses through the health allowances for financially 
International Journal of Ageing and Later Life

disadvantaged pensioners. Second, the interviewees have a habitual capacity to ensure their ontological safety; thus, they have arrangements with the bank to ensure that fixed expenses are paid, leaving them with a disposable amount to spend on groceries and other daily necessities. However, ensuring that the monthly budget for non-fixed expenses actually suffices requires hardline frugality and thriftiness, as is discussed in the following section.

\section{Careful and Thrifty Spenders}

Most of the interviewees admit that they need to be thrifty and practice restraint to make sure that the money lasts for the entire month. Several interviewees explain how they split their monthly food budget into four weekly portions. Inga (74 years old) stated:

Then I saw this thing on a TV show about putting the money in envelopes and hiding them and taking one every week. I thought, "I'm going to do that!" Because it cannot be true that when we get to the 27th I have nothing left for the rest of the month. I don't want that anymore; that's why I did it like that. So, every Friday I put 500 DKK [USD 80] in my pocket for cigarettes and groceries.

Their everyday lives are largely structured by their financial scarcity, which requires them to apply thriftiness to get by, and financial thoughts and worries play a crucial role in their everyday lives. The interviewees save money on groceries by frequenting the cheapest discount stores, searching for food at reduced prices, and traveling to supermarkets at the other end of town ${ }^{6}$ to save a few coins on a loaf of bread or a bag of coffee (and making sure they buy extra to store for later). Eighty-year-old Magda explains that she happily travels through town to obtain good deals, and she always takes her shopping cart to ensure she does not miss out on a great deal because something is too heavy to carry home:

${ }^{6}$ Another way in which the welfare state provides help for state pensioners is by providing them with a pensioners' pass for public transportation. With this pass, state pensioners and disability pensioners can travel on public transportation at significantly reduced prices, for example, 3 months in greater Copenhagen for DKK 460 (USD 73). The regular price is DKK 1575 (USD 252). Thus, the cost of public transportation is not a concern. 
Interviewer: And perhaps you have become an expert at finding cheap groceries in the supermarket?

Magda: $\quad$ Yes, yes, indeed. I go all the way to Rema 1000 if they have cheap coffee or something else - I can do that - and I like doing that. To Aldi and Lidl, or other supermarkets, I do that....

Interviewer: Wherever there is a good deal?

Magda: Yes, indeed; that's really important. Rema 1000 has amazing deals, but it is far away. But then I have this little wagon I bring there [...]. The worst thing is large bottles of soda or glasses with pickled gherkins or beetroot, they are so heavy....

The interviewees also try to make their groceries last as long as possible. For example, Tulle admits that sometimes she skips a meal to make the groceries in her fridge last a bit longer. Although none of the other interviewees admit to skipping meals for economic reasons, they put considerable thought into making their food last. For example, 75-year-old Johanne buys minced meat at a reduced price - due to a nearing expiration date - which she splits into four portions and adds a lot of beans and lentils to create many cheap meals.

When it comes to buying clothes and shoes, the interviewees apply the same carefulness and frugality. They consistently point out that they do not need many new clothes or shoes because they have accumulated a sufficient number during their lifetime and do not wear them out often anymore. Thus, there is no need to buy anything new. Nevertheless, when they do require new clothes or shoes, they save up for them or buy them on sale or secondhand. Eighty-one-year-old Ruth explains that although the amount of money is small, she does not miss out on anything because she buys only cheap clothes:

But see how little [money] is left. But I don't miss out on anything. Clothes and the like I don't miss because I use a lot of secondhand clothes, and buy them when they are cheap or on sale. I never buy clothes for [more than] several hundred DKK [USD 30-40]. (from interview with Ruth)

Getting a good deal on clothes and regular shoes is not difficult for the interviewees. However, some have problems with their feet, requiring new, 
International Journal of Ageing and Later Life

sensible shoes, or even specially made footwear. Several explain that they often cannot afford to buy new shoes when needed, so they wear old shoes that are worn out. This situation is exemplified by 79-year-old Wilfred:

Interviewer: How about footwear?

[Wilfred shows me his feet with sensible-looking, footshaped Ecco shoes.]

Interviewer: Those are some sensible shoes you've got there.

Wilfred: But look here... [He points at the very thin and skewed worn sole of his shoes.]

Interviewer: Indeed, you're right! It is not easy finding footwear secondhand.

Wilfred: Oh, you know what? One may not use that. You know, I have nerve inflammation in my feet; it would be a disaster to me. But clothes, I can use those. For example, when it gets cold, I buy warmer things.

The interviewees are good at making ends meet because they are frugal and thrifty. Nevertheless, they reveal that they experience material and subjective deprivations in their daily lives. Some cannot afford to buy specific groceries and household items, such as fresh fruit, roast beef, psyllium (to counteract the negative effects medicine may have on the stomach), new clothes, footwear, or stronger prescription glasses when needed. Others manage to afford such items by saving money on electricity and heat; therefore, they live in apartments that are (too) sparsely lit and heated. The majority of the interviewees also claimed that they cannot always afford to invite guests for meals in their home, go on vacations, or buy presents for grandchildren and other family members. Some have been forced to cut down on birthday and Christmas presents, and others have stopped giving presents at all, but they expressed feelings of shame about doing so. Their experience of deprivation underlines the severity of their financial condition. However, they retain a feeling of satisfaction, and they continue to make ends meet but not because they have plenty of money.

Despite (or because of) their overall hardline thrift and austerity and the experience of deprivation, the interviewees are able to afford a little 
extra something in their everyday lives that is not essential to their physical survival. The majority of the interviewees explain that they manage to save up a little money to spend on small pleasures, such as buying coffee and cake while reading the free magazines at the library; enjoying a glass of wine at an art exhibition; going to the public swimming pool, a fitness class, or the gym; buying presents for their family; eating lunch at a café; or going on a small excursion. In the following extract, 74-year-old Inga captures this pleasure:

If I am going to spend money on pleasure, then I don't know... See that ashtray next to you, it has a lot of small coins, I put those in a bottle, and on the first of December and June, I empty it, and then I can allow myself other things. I like going to flea markets, where you can find cheap blouses and that sort of thing, right. That's my pleasure. Or out of the blue, I say to my son, "Let's go out to eat a Wiener Schnitzel!" He does that on his birthday, and so do I. But it is expensive if you are to pay 500 DKK [USD 80] for two persons to eat out on your own. One can barely afford that...

Buying presents for grandchildren and other family members is an important topic for most of the interviewees. Many of Tulle's family live in another part of the country, and although the train ticket is expensive, she managed to save up, not just for the train ticket but also for Christmas presents. However, she has reluctantly cut down recently, as she can no longer afford the expense.

The analysis has shown that the interviewees manage to make ends meet in their financially scarce everyday lives due to the thriftiness they apply. Their everyday lives in modern poverty are dominated by their continuous carefulness and frugality, and they carefully control how much money they spend. When it comes to money, nothing happens by coincidence. However, despite their constant thriftiness, they continue to experience deprivations. Therefore, the interviewees implement strict saving strategies, so that they can afford to do some of the small things they enjoy.

This section has provided an understanding of how the interviewees manage their everyday lives. The following section aims to understand how they experience their everyday lives in financial scarcity by linking it to their habitual practical sense. 
International Journal of Ageing and Later Life

\section{The Sense of Financial Scarcity}

Tulle: Well, there are lots of things that you would like, that you nonetheless have to do without, right?

Interviewer: Do you have any specific examples?

Tulle: $\quad$ No, actually not $[\ldots]$ yes; I would like a really nice roast (laughs). But no - I don't know - because I'm used to writing a shopping list, and I know what I need and what I'm used to. So, one might say that my way of shopping is monotonous. Well, I do live very monotonously, I believe.

When asked if there was anything in the supermarket she refrains from buying, Tulle finds it difficult to think of something, and when she does come up with one thing (a nice roast), she immediately dismisses it, referring to her habit of writing - and sticking to - her shopping list. In addition, when I asked Ruth how she hypothetically thinks her life would have turned out if she had had more money, she finds it a somewhat ridiculous question.

Although the interviewees always have to be thrifty and mindful of how they spend their money, they do not consider it a struggle. Everyday life in financial scarcity appears to the interviewees as the only real way of living, and being thrifty is a natural part of their daily existence. Thus, they do not reflect upon how to be frugal - they just are frugal. In addition, when they cannot afford to buy something, such as clothes, they make a virtue of necessity by underlining that they do not really need it.

Everyday life in financial scarcity is not unfamiliar. Most of the interviewees have lived in restricted financial conditions for their entire lives. ${ }^{7}$ For example, 85-year-old Karen grew up in financial scarcity during the Second World War, and after her father died, her mother provided for the family by selling cow's milk to the dairy and eggs to the local shop,

\footnotetext{
7 Unlike the rest of the interviewees, Wilfred, Mary, and Inga did not live in financial scarcity when they were employed. However, they experienced financial scarcity in their childhood, which may explain why the adjustment to the financial scarcity in their retirement does not appear to them as a big deal.
} 
and by digging peat. Later, when Karen got married and had six children, she never had much money, either. In other words, thriftiness is the only way of life with which she has ever been familiar:

Interviewer: How was your financial situation earlier in your life, in your childhood and...?

Karen: Well, it wasn't that good. I never made a lot of money, as I only had that cleaning job at the school, and it was only a couple of hours every day, so it hasn't been much, really. And for several years, I wasn't in the labor market at all. But back then I didn't really ... I mean, it was my own money. But no, we never had more money than we could spend, or more money than we needed.

Interviewer: Perhaps you have become good at knowing how to....

Karen: $\quad$ Yes, and I think that you have to prioritize, I mean, think about how you spend your money, and whether you can do without this or that - you might as well do it like that. I think we have been quite good at that, if I may say so. Certainly, it all turned out fine.

$[\ldots]$

Karen: $\quad$ But I've never been used to spending a lot of money. No. Well, but I guess that we got used to this from the beginning. Yes, I believe so.

Karen characterizes her adult life as a life in financial scarcity and explains how this taught her to prioritize, to do without, and to think through how she spends her money. Similar to Karen, the majority of the interviewees' childhoods and adult lives were dominated by financial scarcity. In addition, as mentioned, owing to their current phase of life being outside the labor market, their financial situation is unchangeable. Thus, they have no way to actively change the situation, for example, by getting a job, and their only real option is to accept and adapt to their situation. However, because of their shared practical sense of the game of financial scarcity, they know how to make ends meet, and they do not feel that they miss out on anything. Several interviewees explain that their current life 
International Journal of Ageing and Later Life

might be less scarce, more financially predictable, and filled with fewer financial worries compared to their younger days when they had to care for small children.

\section{When the Financially Scarce Lifestyle is Challenged by the Societal Context}

Having a practical sense of the game of financial scarcity ensures that the interviewees do not have to logically control or reflect on how to make ends meet; thus, in general, they are quite satisfied. Nevertheless, frustrations occur, as some of the interviewees admit to experiencing feelings of embarrassment, shame, and jealousy because they are aware that most others (family, friends, and society in general) have more money, and therefore, are able to afford larger or better presents for grandchildren, costlier homes, and fancy things, and to travel. In some of the interviews, these frustrations appear from time to time as small notions, which are not elaborated further. In other interviews, however, specifically with Tulle, the frustrations are described directly: Tulle worked as a cleaning lady at a school, and she reveals that she is jealous of her former colleagues because they have more money than her, and they can afford nice houses and cars.

Tulle: Sometimes people ask me if I get a pension from my [deceased] husband; no, I don't. And we hadn't saved up anything. You know, my husband was not paid much in his job, so we didn't think that there was anything to save up with; we didn't think so, so no, I don't have any pension after him. Some of my friends have pensions from their husbands; that's why they can afford to go out for dinner [laughs] [...] $I^{\prime} m$ still in contact with some of the teachers from the school, we have created a pensioner's club, and we meet three or four times a year. Last week, we visited one of them, and I got a ride with my old school inspector, so it was free. But I can see that they have their large pensions; they can afford it all, they have a house and a car and all that, right, so they can afford it all [her voice became very shrill].

Interviewer: What do you think about that? 
Tulle: I'm jealous of course! [Fake laugh], but one shouldn't be! Well, that's just how it is. My old school inspector, she owns a large house, and that's just how it is, right. And the secretary, she is also doing damn well.

Though the other interviewees are not all as direct as Tulle in admitting any jealousy, the feelings of jealousy or shame are evident in most interviews to varying degrees. Bourdieu's (2008) concept of a cleft habitus might be useful for understanding the opposites of the practical sense of the game of financial scarcity on the one hand, and feelings of jealousy and shame on the other. A person might experience a cleft habitus when torn between two contrasting worlds, when the individual's habitus does not correspond to the structures of the social world in which he or she lives (Bourdieu 2008). The individual is caught in contradictions, which may result in a sense of insecurity and self-doubt (Bourdieu 2000: 163). The interviewees' habitus, enabling them to manage their daily lives of financial scarcity does not correspond to the current relatively rich Danish society, in which they have less money than most; thus, their possibilities of taking part in what's considered normal in society are diminished compared to others. Although the interviewees manage to make ends meet, their reflexivity and awareness of their financial situation compared to others give rise to the cleft in their habitus.

\section{Concluding Remarks}

The everyday life of state pensioners living in relative and modern poverty in Denmark is characterized by financial scarcity, and by a frugal and thrifty approach. Despite their ongoing thriftiness, they experience social and material deprivations. However, a general feeling of satisfaction is characteristic of the interviewees' experience of life in financial scarcity, and the empirical analysis suggests several interpretations of this satisfaction on the individual and structural levels. In the analysis, I link the general feeling of satisfaction to the fact that they actually manage to get by.

First, the interviewees' general satisfaction can be linked to the basic safety net provided by the welfare state. For example, state pensioners are ensured a certain minimum income, a housing subsidy, a health allowance for medical expenses, and for those living in senior apartments 
International Journal of Ageing and Later Life

rented through the municipality, automatic deduction of the rent and housing subsidy. This setup allows them a sense of freedom and financial flexibility, albeit on a somewhat smaller scale than the rest of society. Second, the interviewees' general satisfaction can be linked to their shared habitual disposition, providing them with a pre-reflexive practical sense of the game of financial scarcity, which is well-known and natural to them. Their habitual disposition has given them a sense of the paramount importance of paying the rent on time to ensure their basic safety, and with a natural sense of being frugal and thrifty. In addition, their thriftiness and frugality allow them to afford small things in life that are not necessary for their physical existence but are crucial to their experience of satisfaction with everyday life, such as buying a glass of wine or a cup of coffee and purchasing presents for grandchildren. The interviewees' shared habitus and practical sense reveal the societal aspects. The individual ways of experiencing and managing everyday life are not purely individual; they also connect the individual to the wider societal context of their current and previous lives. Although frugality and thriftiness are natural and taken for granted, the majority of the interviewees revealed feelings of shame and jealousy, not because their daily life is rough but because they are aware that other people in society have more money and more possibilities than they do.

However, although all the interviewees benefit from the resources enabling them to lead a satisfying life, some also benefit from resources in their social networks. Some have no or small social networks, and others have large social networks from which to obtain pocket money, inherit electronic devices, and obtain practical help, which they otherwise might have to do without. This aspect of social capital explains some of the crucial differences between the everyday lives of the interviewees because although they all have similar financial conditions, some have saved up social capital, which provides them with the opportunity to modify or enjoy breaks from the otherwise overpowering financial scarcity.

This paper makes an empirical contribution to the literature on financial scarcity in old age because the study illustrates the subjective experiences of and actual ways of making ends meet in financial scarcity in old age at individual and structural levels. The results show how similar financial conditions can hide different daily lives ranging from poor to more "normal" lives in the context of the rich modern society. 
Further, this paper offers a rich insight into what kind of life people who are currently old might be satisfied with; however, future generations of old people may not have the same practical sense of financial scarcity and may not be adapted to such an austere lifestyle, thus making a reasonable living from the current state pension harder than it is today. In addition, Danish welfare services currently provide an important contribution to ensure the basic safety and life satisfaction of old people. However, ongoing demographic changes might prevent the welfare state from providing the same quality of welfare services as today.

\section{Acknowledgements}

This study is financed by VIVE - The Danish Center for Social Science Research, and the EGV Foundation (Social inclusion of older people)."

\section{Corresponding Author}

Rikke Nøhr Brünner, VIVE - The Danish Center for Social Science Research, Herluf Trolles Gade 11, DK 1052, Copenhagen, Denmark. Email: rnc@vive.dk

\section{References}

Allardt, E. (1975). Att Ha, Att Älska, at Vara [Having, Loving, Being]. Lund: Argos Förlag.

Andersen, T. M., Andersen, L., Fløtten, T., Pedersen, L., Ploug, N. \& Sjursen, J. (2013). En Dansk Fattigdomsgrænse - Analyser Og Forslag Til Opgørelsesmetoder [A Danish Poverty Threshold - Analyses and Proposals for Calculation Methods]. Copenhagen: Ekspertudvalg om fattigdom [The Expert Committee on Poverty].

Baadsgaard, M. \& Brønnum-Hansen, H. (2012). Social Ulighed i Levetiden [Social inequality in life expectancy]. Copenhagen: Arbejderbevægelsens Erhvervsråd.

Bourdieu, P. (1986). The forms of capital. In J. G. Richardson (ed.), Handbook of Theory and Research for the Sociology of Education (pp. 242-258). New York: Greenwood.

Bourdieu, P. (1990). The Logic of Practice. Cambridge: Polity Press. 
Bourdieu, P. (1993). Sociology in Question. London, Thousand Oaks \& New Delhi: SAGE.

Bourdieu, P. (2000). Pascalian Meditations. Cambridge: Polity Press.

Bourdieu, P. (2008). Sketch for a Self-Analysis. Chicago and London: University of Chicago Press.

Brinkmann, S. (2015). Etik i en kvalitativ verden [Ethics in a qualitative world]. In S. Brinkmann \& L. Tanggard (eds.), Kvalitative Metoder. En grundbog [Qualitative methods. A textbook]. (2nd ed., pp. 463-480). Copenhagen: Hans Reitzels Forlag.

Brünner, R. N. \& Andersen, S. S. (2018). Making meaning of fiancial scarcity in old age. Journal of Aging Studies, dec., vol. 47, 114-122.

Dominy, N. \& Kempson, E. (2006). Understanding Older People's Experiences of Poverty and Material Deprivation. Bristol: Department for Work and Pensions Research.

Due, P. (1994). "Det er det, når man er alene, kan man gøre, som man vil." Livsløb og helbred hos gamle, enlige og fattige kvinder i Danmark ["It is like, when you are alone, you can do whatever you want. " Life course and health of old, single and poor women in Denmark]. In A. Helset (ed.), I Lyst Og Nød - Livssituasjonen for Gamle Kvinner med Minstepensjon i Danmark, Norge og Sverige [Ups and Downs - The Life Situation for Old Women on Low Pensions in Denmark, Norway and Sweden] (pp. 21-120). Norsk Gerontologisk Institut.

Ejrnæs, M., Larsen, J. E. \& Müller, M. (2015). Copingstrategier og arbejdsløshed [Coping strategies and unemployment]. In M. Møller, M. A. Hussain, J. E. Larsen, H. Hansen, F. K. Hansen \& M. Ejrnæs (eds.), Fattigdom, Afsavn og Coping, [Poverty, Deprivation and Coping] (pp. 153-180). Copenhagen: Hans Reitzels Forlag.

Finch, H. \& Elam, G. (1995). Managing Money in Later Life: Qualitative Research among Retirement Pensioners. London: HMSO Departmentt of Social Security, Social and Community Planning Research.

Gabriel, R., Oris, M., Studer, M. \& Baeriswyl, M. (2015). The persistence of social stratification? A life course perspective on poverty in old-age in Switzerland. Swiss Journal of Sociology 41(3): 465-487.

Golden, J., Conroy, R. M., Bruce, I., Denihan, A., Greene, E., Kirby, M. \& Lawlor, B. A. (2009). Loneliness, social support networks, mood and wellbeing in community-dwelling elderly. International Jounal of Geriatric Pcychiatry 24: 694-700. 
Grech, A. G. (2012). Evaluating the Possible Impact of Pension Reforms on Future Living Standards in Europe. London: Centre for Analysis of Social Exclusion LSE.

Gubrium, J. F. \& Holstein, J. A. (2000). Introduction. In J. F. Gubrium \& J. A. Holstein (eds.), Aging and Everyday Life, Blackwell Readers in Sociology (pp. 1-11). Oxford: Blackwell Publishing Ltd.

Hoff, M. (2006). Livshistorier. Teori og tolkning [Life stories. Theory and interpretation]. In J. Havelund \& A. M. Jensen (eds.), Reminiscens og Livshistorie - Lad Livets Fortællinger Blomstre [Reminiscense and Life Story - Let the Stories of Life Blossom] (pp. 99-119). Copenhagen: Munksgaard.

Keith, V. M. (1993). Gender, financial strain, and psychological distress among older adults. Research on Aging 15(2): 123.

Kvale, S. \& Brinkmann, S. (2015). Interview. Det Kvalitative Forskningsinterview Som Håndværk [Interview. The Qualitative Research Interview as a Craft] (3rd ed.). Copenhagen: Hans Reitzels Forlag.

Leeson, G. W. (1999). Ældre i Byen, Storbyen Og På Landet [Old People in the Town, City, and in the Country]. Copenhagen: Eldre Sagen.

Lister, R. (2004). Poverty. Cambridge: Polity Press.

Litwin, H. \& Sapir, E. V. (2009). Perceived income adequacy among older adults in 12 countries: Findings from the survey of health, ageing, and retirement in Europe. The Gerontologist 49(3): 397-406.

Litwin, H. \& Meir, A. (2013). Financial worry among older people: Who worries and why? Journal of Aging Studies 27: 113-20.

Longva, S. (1993). Levekår i Norge: Er Graset Grønt for Alle? [Living Conditions in Norway: Is the Grass Green for Everyone?]. Oslo: Statens Forvaltningstjeneste.

McKay, S. (2004). Poverty or preference: What do "consensual deprivation indicators" really measure? Fiscal Studies 25(2): 201-223.

Miller, J. \& Glassner, B. (2011). The "inside" and the "outside": Finding realities in interviews. In D. Silverman (ed.), Qualitative Research (pp. 131-148). London: SAGE.

Mood, C. \& Jonsson, J. O. (2016). The social consequences of poverty: An empirical test on longitudinal data. Social Indicators Research 127(2): 633-652.

Phillipson, C. (2013). Ageing (1st ed.). Bristol: Policy Press.

Price, D. (2010). Measuring Material Deprivation in Older People. London: Institute of Gerontology, King's College London. 
International Journal of Ageing and Later Life

Scharf, T., Bartlam, B., Hislop, J., Bernard, M., Dunning, A. \& Sim, J. (2006). Necessities of Life: Older People's Experience of Poverty. London: Help the Aged.

Schultz, I. (2005). Kampen om at definere virkeligheden: Journalisten, forskeren og interviewet som et møde mellem to felter [The battle on defining reality: The journalist, the researcher and the interview as a meeting of two fields]. In M. Järvinen \& N. Mik-Meyer (eds.), Kvalitative Metoder i et Interaktionistisk Perspektiv [Qualitative Methods in an Interactionistic Perspective] (1st ed., pp. 73-94). Gylling: Hans Reitzels Forlag.

Schwartz, A. M. (2006). Pension System Reforms. Social Protection. The World Bank. Washington, DC.

Stjernø, S. (1985). Den Moderne Fattigdom [The Modern Poverty]. Oslo: Universitetsforlaget AS.

\section{Web references}

borger.dk (2018). Available on https://www.borger.dk/pension-ogefterloen/Folkepension-oversigt (Accessed: July 06, 2018)

UNESCO.ORG (2018). Available on http://www.unesco.org/new/ fileadmin/MULTIMEDIA/HQ/SHS/pdf/Soc_Sci_Code.pdf (Accessed: November 06, 2018)

Statistics Denmark (2018). Available on https:/ / www.statistikbanken.dk/ statbank5a/default.asp?w=1422 (Accessed: July 06, 2018) 